\title{
Etiquette of second remarks in social networks (illustrated with examples of social networking "Country of moms")
}

\author{
E. A. Shcheglova \\ St. Petersburg State University, \\ 26, 1-ia liniia V. O., St. Petersburg, 199004, Russian Federation
}

For citation: Shcheglova, E. A. (2019). Etiquette of second remarks in social networks (illustrated with examples of social networking "Country of moms"). Media Linguistics, 6(2), 263-273.

https://doi.org/10.21638/spbu22.2019.210

The paper offers the author's idea on social networks as a subject for research in the sphere of criticism of media speech, namely, from the point of view of compliance with the etiquette principles in the communication process. As a linguistic material, the social network for parents "country of moms" was chosen: it brings together women of reproductive age to discuss issues related to family and children. Discussion in social networks develops a dispute model, yet it has a spiral structure. This makes it particularly interesting to consider the second remarks of dialogues in terms of possibility or impossibility of turning them into remarksincentives, which is largely due to their compliance or non-compliance with the norms of network etiquette. In the study, such models of the second remarks as a remark of response, a remark of argument, a question, a blocker question, a blocker remark were defined. It was found that an important manifestation of second remarks' etiquette is the principle of using citation in them. When the user is focused on the constructive continuation of the dialogue (in remarks-reponses and remarks-arguments), the citation is carried out by means of lexical formulas that are semantic dominants of the discussion and that allow the interlocutors to establish (or confirm) the subject of the dispute, their assessment and behavioral attitudes (motivation). When provoking a refusal to communicate or continue the discussion in a destructive way, this principle of etiquette is not observed: the user either shifts the semantic accents towards semantically less significant, but more advantageous ones from the perspective of the opponent's speech disorientation elements (this is typical for the blockers - questions), or develops his/her own formulas, engaged in self-citation at each turn of the discussion (in remarks-blockers).

Keywords: etiquette, social networks, the second remarks, dialogue, comment.

Problem statement. Social networks "are online platforms designed to organize, reflect, and structure social relationships in the Internet" [Samsonova 2018: 413]. There are several approaches to the study of social networks in modern science, depending on the scientific direction in which they are studied. One of the vectors of understanding this phenomenon is the consideration of social networks as a kind of social media along with blogs, forums, messengers, etc. [Scott 2010]. At the same time, social networks are an open communication system and have the form of a dialogue, which is formed by users' remarks and has a spontaneous and situational character. Like any dialogue,

(c) Санкт-Петербургский государственный университет, 2019 
a dialogue in social networks needs to be harmonized which is a necessary condition for effective communication. It is well-known, a harmonious dialogue is determined by the following conditions: "1) the consistency of the interlocutors' strategies and tactics; 2 ) tone of communication, mutually acceptable for the communicants; 3 ) sincere (not ostentatious) interest in the subject of discussion, as well as in the content of what was said by the interlocutor; 4) adequate verbal and non-verbal embodiment of the participants' communicative attitudes in the dialogue; 5) achievement of at least partial understanding and agreement of the parties in the process of speech act" [Kolokoltseva 2009]. However, within the social networking, the nature of harmonization is defined by the following trends: 1) using units typical of the spoken language, - colloquialization; 2) game-style expressivity; 3) poly-codes used; 4) reduction and coarsening of speech style associated with lack of users' education, and with the anonymity of communication in social networks [Matusevich 2016]. Thus, it can be assumed that a social network is a communicative system characterized by special ethical and aesthetic characteristics of speech behavior caused by the pragmatics of communication in the network. In particular, the network etiquette as a means of dialogue harmonization, opposing speech aggression, which is perceived by the addressee as a threat, insult, dislike, etc., has its own peculiarities [Maidanova 1997]. Consequently, one of the possible approaches to the study of social networks may be considering them in line with the criticism of media speech, which also considers media speech in terms of its compliance with ethical and aesthetic norms [Vasilieva 2018: 45]. Although research in this area mainly concerns in the speech activity of a professional in the media sphere [Bessarabova 2015; Surikova 2004], we should also consider changes in the norm of network communication, their compliance or non-compliance with constant norms (politeness, respect for the interlocutor, truthfulness, ability to listen).

Background. The concept of "social networks" has been actively used in sociology since the middle of the last century, but in a different meaning than it is assumed in this study. Social networks were understood as social groups (organizations) of different levels (see [Travers, Milgram 1969; Fischer 1982; Wellman 1979] and many others). Currently, social network analysis is an actively developing interdisciplinary research practice [Bearman, Moody, Stovel 2004; Koester, Glanz, Baron 2005], which is based on mathematical graph theory and empirical research in anthropology and sociology. In this case, the so-called nodes and the interactions between them are studied. With the emergence and development of the Internet space, some of these studies began to use electronic resources as empirical material.

Now social Internet networks are actively studied by methods of various sciences: in sociology [Castells 1996; Dulina, Efimov, Nebykov, et al. (ed.) 2014; Efimov 2015], in philosophy - as a system that has the properties of autopoiesis and causes the subject transformation [Lavrenchuk 2011], in psychology — in terms of virtual reality' impact on mental development and human health [Nosov 1997], in the theory of journalism - as a form of electronic media [Akopov 1998].

Social networks also become a subject of analysis in linguistics: first, in the framework of general arguments about the language in the Internet and its influence on the Russian language [Kostomarov 2005; Goroshko 2007], and secondly, in the works on the verbal behavior of social network users [Popova, Voznesenskaya, Kolesova and others 2012; Grishanina 2017; Fisher, Smith, and Welser 2006]. 
There are also a few works on speech etiquette in social networks, however, they consider it narrowly as the norm of politeness speech formulas use [Zoltner, Shaburova 2017]. L.R.Duskaeva writes: "Speech etiquette in mass media is a speech resource specific not only for the media sphere as a whole, but also for the speech types and forms in it, aimed at harmonizing communication: cooperation, taking into account the communicative interests of the addressee, his/her needs, thematic and ideological preferences" [Duskaeva 2018: 235]. A complex consideration of speech etiquette in social networks as a means of speech activity harmonization in different situations of communication: (about etiquette in this sense also: [Duskayeva, Kornilova 2012]) has not yet been undertaken. Meanwhile, the relevance of the stated problem is obvious, which is proved by numerous "non-professional" generalizations on speech etiquette in social networks, as a rule, which are a set of rules or tips for a generalized user of a generalized network (for example: " 15 golden rules of etiquette in social networks" («15 золотых правил этикета в социальных сетях»), Interesno. 14.11.2016; "15 rules of etiquette in social networks, which are shameful not to know” («15 правил этикета в социальных сетях, которые стыдно не знать»), Cosmopolitan. 4.11.2017 and the like). In this study, it is expected to consider speech means of harmonization and dis-harmonization of a dialogue in different models of the second remarks in social networks illustrated with examples from "Country of Moms".

Research methods. For the development of the presented problem we used the whole complex of methodological tools of linguistic and stylistic text analysis. The study involves several stages:

1) identification of the second remarks models in the dialogue of the social network for mothers;

2) definition of speech tools aimed at harmonization or dis-harmonization of the dialogue;

3) establishment of pragmatics of the found speech means' use depending on the strategy of speech behavior chosen by the specific user.

Material analysis. The social network "Strana mam" (https://www.stranamam.ru/) is a platform for the parental (or future parents') discussion of various issues, mainly relating to children, family relations and leisure activities. The network brings together women of different ages, levels of education and social status (men are much less likely to be members of such communities).

Communication mainly has a value-oriented character - to a greater extent, of course, they are talking about family values. The mission of the network is formulated by the resource administration as follows: "our network is created exclusively for pleasant and interesting communication, useful for its participants", that is, one can observe the initial orientation to harmonious communication among the participants. Compliance with the rules of the forum is followed by the moderators and administration. The main prohibitions relating to speech behavior are the ban on obscene vocabulary use, on transition into personal matters, the incitement of ethnic.

In this case, the models of the second remarks and the manifestation of etiquette in each of them are considered basing on the example of "Public breastfeeding" discussion. The material was chosen not by chance: firstly, its significance is due to the resonance of this topic among the network users, which is confirmed by a large number of comments (7440 at the time of writing this paper; only broad topics related to the overall health of 
mother and child have more comments); secondly, it is focused on value-oriented discussion, due to the theme; third, the users express opposite points of view on the problem submitted to the initial post (whether to feed or not to feed a baby in public).

The structure of any social network discussion can be presented as follows:

- initial post (stimulus cue);

- reactions of the first row (remarks-incentives for secondary remarks of the second row);

- remarks-reactions of the second row...

Discussion initiates a new discussion, splits into local discussions affecting individual users. Thus, there may be remarks-reactions of the third row, of the fourth row, etc. Each second remark can, in its turn, become a remark-stimulus, and a possible basis for their classification is the ability to undergo this transformation, which will depend on compliance or non-compliance with the etiquette principles.

In this regard, the discussion is often cyclical, going back to the initial post, then going into private discussions. The number and nature of such cycles is largely determined by the theme.

I. M. Voznesenskaya distinguishes two types of user's verbal behavior at the dedicated forum: aggressive and logical-rational types of discussions [Popova, Voznesenskaya, Kolesova and others 2012: 44]. With regard to the second remarks, this is manifested, firstly, in the general willingness to continue communication, and secondly, in the nature of communication, which the second remark is focused on - a potential remark-stimulus. Thus, the second qualitative characteristic of the second remarks' models is their orientation to constructive or destructive communication. This orientation is manifested in the character of the citations of the second remarks as their constructive feature [Arutiunova 1986; 1990].

We consider the second remarks' models focused on continued communication to be remarks of response, remarks of argument and questions.

A response-remark is the answer to the question asked in the initial post. This type is the basis of responding remarks of the first row. Etiquette in this model of the second remarks is manifested in the repetition of semantic dominants, which are a means of expression and formed by the initial post. This becomes especially obvious in the case when the initial post is a survey. For example, in the studied discussion of public breastfeeding admissibility, the author offers users the following question accompanied by answers: Breastfeeding in public: иnacceptable, normal (Грудное вскармливание на публике: недопустимо, нормально). Initially, an evaluation scale is introduced, according to which users are asked to evaluate this mother's action (breastfeeding in public) in relation to the child (orientation to family values). Naturally, it is the evaluative vocabulary along with the designation of the action and the actors that plays the role of keywords in the comments.

Two more positions of semantic dominants are taken by words that give a qualitative characteristic of the action (it often defines the assessment, too) - covered, open (прикрыто, открыто): it is covered, to feed openly, covered breast (это прикрыто, кормить открыто, прикрытая грудь), etc. These positions are also given by the initial post, which the author ends with the following presentation of her/his own opinion: My opinion: if you cover yourself, breastfeeding in public is acceptable (Мое мнение: если 
укрыться, ГВ на публике допустимо) (the presence of another evaluative word - acceptable - shall be noted (допустимо)). Thus, a special formality of users' communication on a certain topic is formed. The content of the second remarks is partly programmed: there are key words that form the content side, evaluation and motivation. At the same time, this programming is often felt by the users themselves, as can be seen from the comments containing language reflection

$$
\begin{aligned}
& \text { lesik_l } \\
& 7 \text { October at 9:08 } \\
& +\mathbf{1}-+ \\
& \text { Covered is the key word (Прикрытая - ключевое слово). }
\end{aligned}
$$

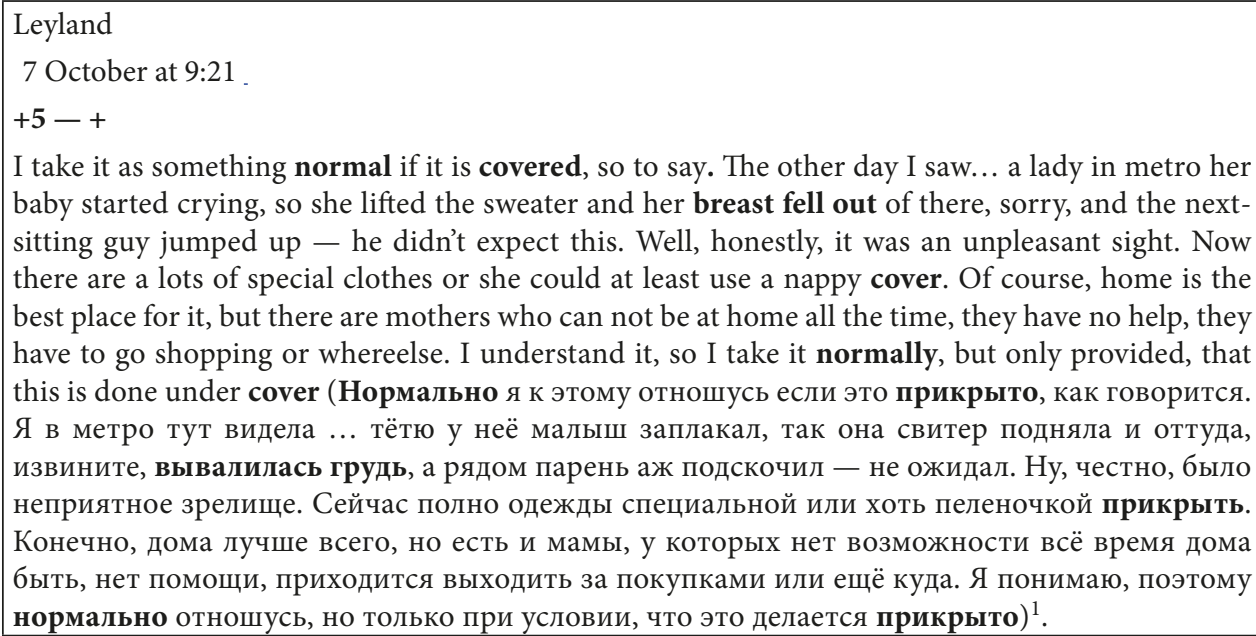

In this case, the choice of lexical units from the synonymic series depends on the position of the user (chest, tit(s), boobs (грудь, сиська (u), сися)). The predicate also often serves as a means of expression of an assessment (she pulled out a boob, the breast fell out (сиську вытащила, вывалилась грудь)).

Remark-argument in favor of the proposed point of view, as a rule, is a remarkreaction of the second rows, appearing in response to a comment containing the opposite point of view. The remark-argument is put forward in defense of the previously expressed position. Peculiarities of etiquette manifestations are similar to the cue-response. The citation is manifested in the same formula elements formed by the initial post and partly by the comment, which became a direct incentive for this remark:

Ninnetta

7 October at 13:34

$+1-+$

Only women are outraged, may be they are afraid that their man will see someone else's breast )))) (Возмущаются только женщины, может бояться, что их мужчина грудь чужую увидит)

\footnotetext{
${ }^{1}$ In the original texts the authors' spelling and punctuation is kept.
} 
mamaLesya 79
7 October at 15:48 .
$+7-+$
What about those boys who haven't even seen a girl's breasts yet? You could modestly turn away or
cover the breast, instead of showing it off defiantly - I'm a mother, what's the problem? (Как быть
мальчишкам, которые ещё даже не видели грудь девушки? Можно скромно отвернуться или
прикрыть грудь, а не вываливать демонстративно - я же мать, а чё такова?)

In this case, the comment, based on the remark-argument model, contains an additional evaluative element in the form of I am a mother (я же мать) formula, used by opponents of public breastfeeding and other attributes of the so-called "natural" motherhood. There is a citation of a different nature: the user quotes a formula common to supporters of his point of view, which is widely used in the Internet space in general, and not only in this particular discussion. In this case, the formula is a provocation for the opposite point of view supporters and a sign of unification for like-minded people, that is, the second remark is initially arranged in such a way as to become an incentive for the continuation of the dialogue. And since the nature of this sign is basically dual, the dialogue can be continued both in a constructive and destructive way.

A question as another model of the second remarks is, as a rule, initially provocative and is used to stimulate a dialogue with users who adhere to the position opposite to the author's comment. Although the same keywords are used in the questions, the nature of their use is qualitatively different from those in responses-remarks and responses-arguments. The keyword can be used to deny the subject of the dispute, for example, as in this case:

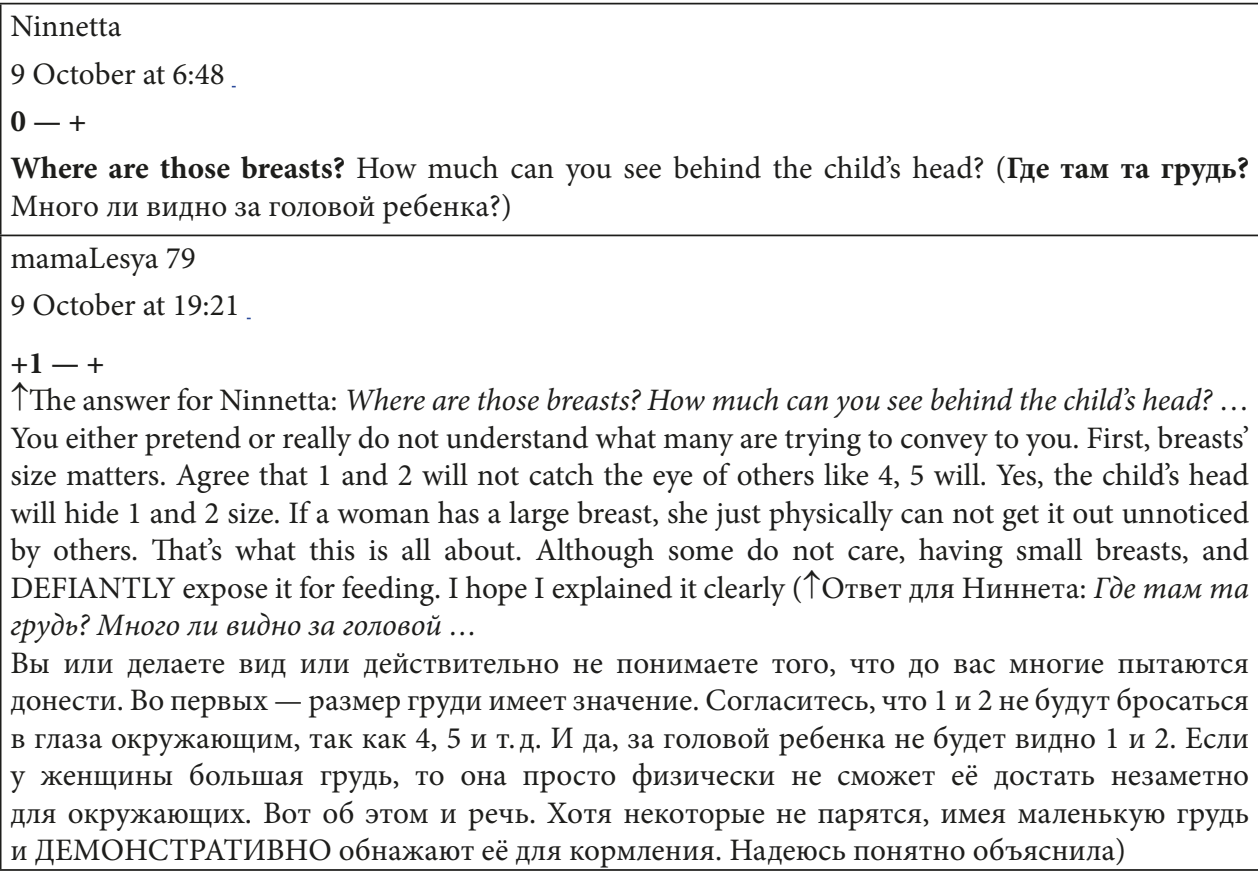


How effective was the provocation in this example, can be judged by the volume of the comment, and the use of graphic selection (CapsLock), as well as by the presence of emoticon, expressing bewilderment, and the number of evaluative vocabulary (to catch the eye, unnoticed, do not care, defiantly (бросаться в глаза, незаметно, не парятся, демонстративно)).

As the second remarks, aimed at breaking communication, we have found such models as question-blocker and remark-blocker in the study material.

A question blocker differs from a simple question in its focus on the lack of an answer. If silence in response to a question in the general situation is a violation of etiquette, the question-blocker by its nature is aimed at "speech paralysis" of the interlocutor. In this case, silence becomes just a means of speech etiquette, in many cases allowing to avoid further conflict.

The citation of the second remark, organized according to the model of the questionblocker, is based on the preceding remark. In this case, the author of the question-blocker chooses no semantic dominants, but positions of someone else's text that are significant for him personally. There is a peculiar semantic and speech disorientation of the opponent, often having a manipulative character. In this respect, the refusal to answer can be also considered a protective reaction of the user, because the response in this case would be a deviation from the theme (the so-called flood), which is punishable by moderators of the network.

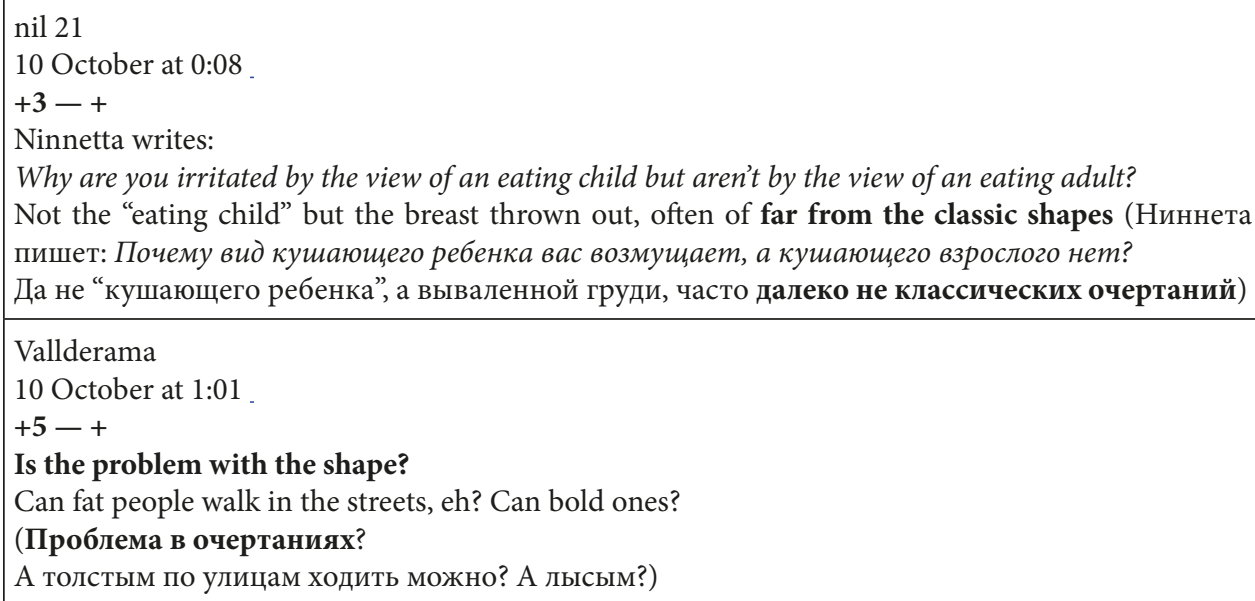

It is obvious that in this case the problem of public feeding was discussed which can also provoke esthetic rejection of people around, it wasn't at all about humiliation of people with appearance other than ideal, but the question- blocker takes the readers away to this subject, being at the same time the hidden charge of intolerance.

Response-blocker is also a means of opponent's speech disorientation. However, the principle of its work is different than that of the question-blocker. Disorientation is not due to the shift of semantic accents and substitution of semantic dominants in the second remark, but due to the complete absence of citation in it. Outwardly, a blocking response, if it occurs in a discussion for the first time, is completely unrelated to the previous discussion: 
MAKAKA

9 October at 19:24

$+3-+$

I read the above sequence of opinions. The main idea is that public feeding, so that everyone can see it - causes rejection... (Читала я выше ветку. Основная мысль - прилюдное кормление, так, чтобы все всё видели - это вызывает неприятие...

Ninnetta

10 October at 6:39

$\mathbf{0}-+$

Don't look at it — and that's all))) (Не смотрите, делов то)

Further on, the author of the response-blocker is engaged in self-citation. Since the network discussion is not a dispute in its classical form and has, as we mentioned above, a spiral composition, the possibility of using the found formula is provided at each "turn". The user, having once found a successful formula, repeats it again and again, while maintaining it almost unchanged with some variability (sometimes up to emoticons use): Do not look at it, and that's all)); Do not look and there are no problems)); Well, if it is unpleasant, you can simply avoid looking; Do not look and there are no problems)) (He cмompume, делов то))); Не смотрите и нет проблем)); Ну если неприятно, то можно просто не смотреть; Не смотрите и нет проблем))). The polite answer to the blocking response, as in the case of the blocking question, is silence.

Research result. The analysis of the material showed that several models of the second remarks can be distinguished: remark-reponce, remark-argument, question, question-blocker, remark-blocker. Each of these models is characterized by its degree of focus on productive communication, and therefore, its degree of etiquette expression. An important manifestation of etiquette in the second remarks is the citation, which helps the addressee to orient in the interlocutor's opinion. For this purpose, key lexical positions are used, which assume the role of formulas, which are markers of the topic of conversation, evaluation and motivation. Through the use of such formulas, the second remarks become, in turn, remarks-stimuli, which form a new round in the spiral structure of discussion in the social network. The imposition of other elements of stimulus-remarks as a semantic dominant or the failure of the already established formulae is the basis of the user's orientation onto destructive communication, as is the case with questions-blockers and remarks-blockers.

Summary. Within the framework of communication in the social network, its own system of etiquette is formed: some comments provoke new remarks, others are focused on interrupting communication or its continuation in a destructive way. Ignoring the latter is not a violation of network etiquette norms, but, on the contrary, a sign of following them.

The norm itself becomes an extremely mobile concept. The difference in the models of the second remarks is, in particular, the ability to turn into remarks-stimuli and to generate remarks-reactions of the next row, which in turn become remarks-stimuli. 


\section{References}

Akopov, A. I. (1998). Social networks as a new kind of media. Filologicheskii vestnik Rossiiskogo gosudarstvennogo universiteta, 3, 29-34. (In Russian)

Arutiunova, N.D. (1986). Dialogic citation (To the other's speech problem]. Voprosy iazykoznaniia, 1, 5064. (In Russian)

Arutiunova, N.D. (1990). The phenomenon of the second remark, or about the benefits of dispute. In $\log$ icheskii analiz iazyka (pp. 175-189). Moscow: Nauka. (In Russian)

Bearman, P., Moody, J., Stovel, K. (2004). Chains of affection: The structure of adolescent romantic and sexual networks. American Journal of Sociology, 110(1), 44-91.

Bessarabova, N. D. (2015). Journalist and word. Moscow: Moscow State University, Department of journalism. (In Russian)

Castells, M. (1996). The Information Age: Economy, Society and Culture. Vol. I: The Rise of the Network Society. Oxford UK: Blackwell Publishers.

Dulina, N. V., Efimov, E. G., Nebykov, I. A. et al. (2014). Socio-cultural development of virtual space: the experience of sociological analysis. Volgograd: Volgograd scientific publishing house. (In Russian)

Duskaeva, L. R. (2018). Speech etiquette in mass media. In Medialingvistika v terminakh i poniatiiakh: slovar'-spravochnik (pp. 235-238). Moscow: Flinta. (In Russian)

Duskaeva, L. R., Kornilova, N. A. (2012). Etiquette speech genres in newspaper discourse. Vestnik Permskogo universiteta, 3(9), 177-185. (In Russian)

Fischer, C. (1982). To dwell among friends. Chicago: University of Chicago Press.

Fisher, D., Smith, M. A., Welser, H. (2006). You are who you talk to: Detecting roles in usenet newsgroups. Proceedings of the $39^{\text {th }}$ Annual Hawaii International Conference on System Sciences (HICSS'06) (HICSS) (pp. 59b). Kauai, Hawaii.

Goroshko, E. I. (2007). Linguistics of the Internet: development of a disciplinary paradigm. In Zhanry i tipy teksta $v$ nauchnom i mediinom diskurse -5 (pp. 223-237). Orel: Kartush. (In Russian)

Grishanina, A.N. (2017). Personality in the social networking coordinates: constructivism and destructiveness of verbal behavior. Gumanitarnyi vektor, 12(2), 109-115. (In Russian)

Koester, S., Glanz, J., Baron, A. (2005). Drug sharing among heroin networks: Implications for hiv and hepatitis $\mathrm{b}$ and c prevention. AIDS and Behavior, 9(1), 27-39.

Kolokol'tseva, T.N. (2009). Culture of dialogic communication (responses-reactions in a dialogue). Elektronnyi nauchno-obrazovatel'nyi zhurnal "Grani poznaniia", 1(2). Retrieved from http://grani.vspu.ru/ files/publics/26_pub.pdf. (In Russian)

Kostomarov, V. G. (2005). Our language works. Essays of modern Russian style. Moscow: Gardariki. (In Russian)

Lavrenchuk, E. A. (2011). Autopoeisis of social networks in the Internet space. PhD thesis. Moscow. (In Russian)

Maidanova, L.M. (1997). Aggression and verbal aggression. In Rechevaia agressiia i gumanizatsiia obshcheniia $v$ sredstvakh massovoi informatsii (pp. 9-13). Ekaterinburg, Ural State University. (In Russian)

Matusevich, A. A. (2016). Communication in social networks: pragmatic, communicative, linguistic and stylistic aspects of the characteristic. $\mathrm{PhD}$ thesis. Kirov. (In Russian)

Nosov, N.A. (1997). Virtual man: essays on the virtual psychology of childhood. Moscow: Magistr. (In Russian)

Popova, T. I., Voznesenskaia, I. M., Kolesova, D. V. et al. (2012). Internet space: speech portrait of the user. St. Petersburg: Eidos. (In Russian)

Samsonova, A. A. (2018). Social networks. In Medialingvistika v terminakh i poniatiiakh: slovar'-spravochnik (pp. 413-416). Moscow: Flinta. (In Russian)

Scott, D. M. (2010). The New Rules of Marketing and PR: How to Use Social Media, Blogs, News, Releases, Online Video and Viral Marketing to Reach Buyers Directly. New Jersey: Hoboken, N. J., John Wiley \& Sons.

Surikova, T. I. (2004). Ethical problems of mass communications language: youth media, political and consumer advertising. Vestnik Moskovskogo gosudarstvennogo universiteta, series 10, 1, 84-89. (In Russian)

Travers, J., Milgram, S. (1969). An experimental study of the small world problem. Sociometry, 32(4), 425443.

Vasilieva, V.V. (2018). Criticism of media speech. In Medialingvistika v terminakh i poniatiiakh: slovar'spravochnik (pp. 45-49). Moscow: Flinta. (In Russian)

Wellman, B. (1979). The community question: The intimate networks of east yorkers. American Journal of Sociology, 84 (5), 1201-1233. 
Zoltner, O. V., Shaburova, E. V. (2017). Etiquette features of Internet communication (based on the material of the communities in the social network "VKontakte"). Kommunikativnye issledovaniia, 4(14), 97-105. (In Russian)

Received: February 10, 2019

Accepted: February 21, 2019

Author's information:

Ekaterina A.Shcheglova — PhD, Associate Professor; e.scheglova@spbu.ru

\title{
Этикет вторых реплик в социальных сетях (на примере социальной сети «Страна мам»)
}

\author{
Е.А. Щеглова \\ Санкт-Петербургский государственный университет, \\ Российская Федерация, 199004, Санкт-Петербург, 1-я линия В. О., 26
}

Для цитирования: Shcheglova, Е.А. (2019). Etiquette of second remarks in social networks (illustrated with examples of social networking "Country of moms"). Медиалингвистика, 6(2), 263 273. https://doi.org/10.21638/spbu22.2019.210 (In English)

Предлагается взгляд автора на социальные сети как предмет для исследования в области критики медиаречи, а именно с точки зрения соблюдения в процессе коммуникации принципов этикетности. В качестве материала была выбрана социальная сеть для родителей «Страна мам», которая объединяет женщин репродуктивного возраста для рассмотрения вопросов, касающихся семьи и детей. Обсуждение в социальных сетях развивается по модели спора, но имеет при этом спиралевидную структуру. Это делает особенно интересными для рассмотрения вторые реплики диалога с точки зрения возможности или невозможности превращения их в реплики-стимулы, что во многом обусловлено соблюдением или несоблюдением норм сетевой этикетности. В ходе исследования были выделены модели вторых реплик, такие как реплика-ответ, реплика-аргумент, вопрос, вопрос-блокатор, реплика-блокатор. Было установлено, что важным проявлением этикетности вторых реплик являются принципы использования в них цитации. При ориентации пользователя на конструктивное продолжение диалога (в репликах-ответах и репликах-аргументах) цитация осуществляется за счет лексических формул, являющихся семантическими доминантами обсуждения и позволяющих собеседникам установить (или подтвердить) предмет спора, свою оценку и поведенческие установки (побуждение). При провоцировании отказа от общения или продолжения дискуссии в деструктивном ключе этот принцип этикетности не соблюдается: пользователь либо смещает смысловые акценты в сторону семантически менее значимых, но более выгодных с точки зрения речевой дезориентации оппонента элементов (это характерно для вопросов-блокаторов), либо вырабатывает собственную формульность, занимаясь самоцитацией при каждом витке обсуждения (в репликах-блокаторах).

Ключевые слова: этикетность, социальные сети, вторые реплики, диалог, комментарий.

Статья поступила в редакцию 10 февраля 2019 г.; рекомендована в печать 21 февраля 2019 г.

Контактная информация:

Щеглова Екатерина Александровна - канд. филол. наук, доц.; e.scheglova@spbu.ru 